\title{
A Welsh bronze age hillfort
}

\author{
H. N. SAVORY
}

In I964 The National Museum of Wales published 'Dinorben: a hill-fort occupied in Early Iron Age and Roman times', in which Dr H. N. Savory made available the late Dr Willoughby Gardner's records of his extensive excavations on this North Wales site and added his report on emergency excavations carried out there by himself more recently for the then Ministry of Public Building and Works, in the path of destruction by quarrying. In 1969 Dr Savory recut one of Dr Gardner's sections through the main southern rampart of the hillfort and several charcoal samples derived from the earlier constructional phases of this rampart have now been dated by the Radiocarbon Dating Laboratory of the Institute of Applied Science of Victoria, Melbourne, from the Ioth to the 5th century $B C$.

So well-established has become the view that hillforts in Britain are a pre-eminently Early Iron Age phenomenon that many prehistorians working today would need to be reminded how firmly their predecessors of two generations ago believed in the Bronze Age date of most of them (Rice Holmes, 1907, 132-9). This old view was finally swept away by Professor Hawkes's classic ANTIQUITY paper of forty years ago (1931, 60-97), or so it seemed. But during the last few years evidence has been coming to light that some, at least, of our hillforts may, after all, have been first built in the Late Bronze Age. As before, ANTIQUITY promptly reflected the new trend by publishing radiocarbon dates which suggest startlingly early dates for some Scottish forts (MacKie, $1969,15^{-26}$ ) and the apparent contemporaneity of exclusively 'Late Bronze Age 2' metalwork, scattered among the occupation débris, with a timber revetted rampart at Ivinghoe Beacon, Bucks. (Cotton and Frere, 1968, 200-3), followed by rumours of similar associations, or early radiocarbon dates, at other southern British hillfort sites not yet fully published, must make us reconsider the possibility that some examples of particular types of hillfort in England and Wales might have been built even before the arrival of those Hallstatt $\mathrm{C}$ invaders who are now beginning to win credence as the true initiators of our Early Iron Age (Burgess, 1968, 26-33; Harding, r97o, 235).
It is, perhaps, somewhat ironical that evidence of very early hillfort building in North Wales should now come from a site which the present writer had some difficulty, not so long ago, in wresting from the Romans. For it is the repeatedly excavated Dinorben hillfort, Abergele (Denb.) which once furnished many of the arguments for Sir Mortimer Wheeler's old theory of North Wales hillforts manned and even built by a Romano-British local militia (Wheeler, I922) which has now yielded radiocarbon dates which suggest that it began as a Late Bronze Age promontory fort. There had, of course, always been the well-known Parc-ymeirch hoard of horse-harness, found over a century ago at the foot of the crags which form the natural western defences of Dinorben (PL. XXXIX), which clearly belongs to the Late Bronze Age and might be thought to be connected with activity on the adjoining hill-top at that time, but in fact until recently there appeared to be no material from early occupation layers explored at various times on the hill-top which could certainly be assigned to so early a phase (Gardner and Savory, 1964,77 f.). Dr Gardner himself found ample evidence for occupation in the late $3^{\text {rd }}$ and $4^{\text {th }}$ century $A D$, and his exploration of successive road surfaces in the later main entrance through the southern defences led him to think that their final reconstruction was of late Roman date and that even the destruction of the first rampart of five 


\section{ANTIQUITY}

in this part of the site had been carried out by the Roman army. The head of a Roman pioneer's axe, recorded by Dr Gardner as found on the lip of the primary ditch, at the foot of the primary rampart (Periods I-II) in the southwestern area of the site, apparently sealed by the débris from that destruction and the vast bulk of the later ramparts, seemed to be strong evidence for that view (Gardner and Savory, I964, 83-5).

When the writer came, in 1964 , to review the combined evidence from Dr Gardner's excavations of $1912-22$ and his own of $195^{6-61}$ for the phases of occupation at Dinorben he could see evidence for nothing earlier than an Early Iron Age village, open at first (Gardner's Period O) then defended on the south, where approach was easy, by a single rampart and ditch (Periods I-II) and finally enclosed by multiple banks and ditches, with a weaker extension in the eastern and northern sides (Period III-V). The chronology of this Early Iron Age occupation was hazy because the associated metalwork, mainly derived from hut-floors some of which were earlier than the north-eastern defences, consisted simply of a few ring-headed pins, penannular brooches and spiral finger-rings; the occasional pot-sherds consisted either of the notorious 'VCP' of the Welsh Marches or rather better quality Iron Age ' $A$ ' ware, some of it then thought to be related to 'Second $A$ ' groups in the English Midlands. The conclusion was that there were no clear indications of occupation of the hill-top at Dinorben before the $3^{\text {rd }}$ century $B C$, and the question of the Late Bronze Age horse-harness found at the foot of the western crags remained separate (Gardner and Savory, $1964,75^{-8}$ ). But it was still obvious that this chronology was not very satisfactory because knowledge of the crucial sequence on the site of the main southern rampart still depended entirely upon Dr Gardner's sections of fifty years ago, made at a pioneering stage of hillfort archaeology, and singularly little dating evidence had been found for the earlier parts of the sequence, apart from the pioneer's axe, although the presence of primitive occupation débris like split pot-boilers and bone tools such as antler picks, combined with the absence of RomanoBritish pottery, in the early layers, suggested that there had been a fairly lengthy prehistoric occupation. At the same time the writer, in 1964 , saw strong reasons to doubt whether the final reconstruction of the southern defences could have been as late as the end of the 3 rd century $\mathrm{AD}$ and he concluded from Dr Gardner's records that the late Roman occupation material at the southern end of the site had in fact accumulated on the rear slopes of the final rampart long after it had been partially demolished (1964, 9 I f.).

Since 1964 the advance of the quarry face at Dinorben has brought the writer's own rescue excavations, carried out on behalf of the then Ministry of Public Building and Works, closer to the southern defences. A section cut through the eastern end of these in 1965 clearly showed that in this area almost the whole of the remains of the ramparts of Periods III-V had been removed, probably by deliberate demolition, before the abundant late Roman material was deposited at this point, and in 1967 exploration of areas including the tail of the main rampart in the south-western area showed that here, too, the Period V rampart had been partially demolished before the Late Roman material was deposited. When he came to prepare the reports on the $x_{96} 6$ and 1967 excavations the writer felt unwilling to leave the chronology of the main rampart still unsettled in what would have to be, as far as he was concerned, a definitive report, and resolved to cut a complete section through it to test Dr Gardner's structural interpretations and to find dating evidence, even though there was no immediate threat of destruction, and he was enabled to do this, in I 969 , by the financial help of the Church Act Funds Committee of the Denbighshire Association, the Cambrian Archaeological Association and the Ministry of Public Building and Works. The main southern rampart at Dinorben, where best preserved, in an area a short distance west of the south-east entrance, is a vast mound, still rising over $9 \mathrm{~m}$. above the bottom of the associated ditch. Further west, however, its height has been reduced by demolition in antiquity and here Dr Gardner's section 19, 


\section{A WELSH BRONZE AGE HILLFORT}

first cut in 1914 , still lay open in 1969 , its sides partially collapsed and its base choked with fallen débris. With fairly limited resources in money and labour, it seemed economical to recut this old section with the help of a mechanical excavator to clear unstratified débris, leaving exploration of a fresh section to conventional digging by student volunteers. In the event, owing to the looseness of the rubble layers which successive reconstructions had interspersed with clay in the body of the rampart, and the considerable total height (PL. xxxviIIa) it was found necessary to stage the section in two tiers for safety reasons, most of the undisturbed lower tier being removed by hand after recording the profile.

The sections recorded by Dr Gardner west of the south-east entrance reveal a long sequence, seen at its most complete in section $I$ but still preserved in section 19 (1964, figs. 7 and 8). At the base is a pre-rampart occupation layer (O) on which rest the remains of an early rampart, with a clay body and a dry-stone outer facing, thought by Dr Gardner to represent two successive phases (I-II), and related to the early entrance, with simple plan, found by Dr Gardner buried in the body of the later south-east entrance. This early rampart had been largely destroyed, with the help of a fire which had turned much of its limestone rubble and facing blocks to quicklime, heaps of which were found at various points under the later rampart, which was twice reconstructed (III-V) and was in its final stage a sloping-fronted mound, with rear terraces revetted by three dry-stone revetment walls. These later ramparts were naturally related by Dr Gardner to the elaborate inturned entrance on the south-east side of Dinorben, which had three successive road surfaces and a pair of rectangular guardchambers inside the gateway, one of which, at least, showed signs of having been twice reconstructed and which now relate to a large series of paired guard-chambers in hillforts of the northern Marches (1964, fig. I5) and the Cotswolds. The re-cut section of 1969 confirmed this sequence in broad outline (FIG. I) but added some interesting details. It was clear that the remains of an early rampart rested on a thick occupation layer and the associated ditch cut through this layer. But it was also clear that the stone outer revetment wall of the early rampart had been preceded by a palisade trench, straight-sided and flat-bottomed, $30 \mathrm{~cm}$. wide and $20 \mathrm{~cm}$. deep in the clay sub-soil, which was traced for a distance of $3 \mathrm{~m}$. on a line parallel with the ditch, and a short distance north-east of its inner lip (PL. XXXVIIIb). It was also found that the red clay bank which Dr Gardner had interpreted as a primary rampart (Period I) rested on a layer of rubble and had running through it at this point four continuous layers of grey clay about $5 \mathrm{~cm}$. thick (FIG. I and PL. xxxvilia); in places, near the south-western edge of the clay bank, the grey clay was replaced by fragments of charcoal which have been identified by $\mathrm{Mr}$ John Davies, of the Department of Botany of the National Museum of Wales, as representing mature oak. It seems that the red clay bank had been constructed of alternating layers of clay and rafts of timber consisting of logs or thick planks laid down side by side and some of the dark, partially charred layers had a zig-zag longitudinal section as though contiguous tranverse beams, flattened by the pressure of the overlying mass of material, had become tilted in relation to the irregularities of the stony layerbelow. Presumably the rafts had been tied to the palisade revetting the outer face of the bank, and it seems likely that a single post-hole which penetrated the pre-rampart occupation layer behind the bank (PL. XxxvIIIc) formed part of a widely spaced line of uprights holding horizontal beams which revetted the rear of the bank. On this interpretation Dr Gardner would be confirmed in his view of the clay bank as a distinct structure (Period I) succeeded by a drystone rampart (Period II). The latter had an outer revetment of massive blocks (PL. Xxxvmib) and a ditch, $2 \cdot 8 \mathrm{~m}$. wide at the mouth and $\mathrm{I} \cdot 2 \mathrm{~m}$. deep; it was clearly the source of a mass of slaked lime which in this area ran in a continuous line under the tail of the final rampart with masses of charcoal adhering to its under surface. This must have been a timber-laced rampart, but in the area explored destruction had been too complete for the method of lacing to be clear. At least there was no sign of vertical timbers, and the 


\section{ANTIQUITY}

structure was probably of the type found in the Abernethy forts of Scotland and at Maiden Castle in Cheshire (Cotton, 1954, 28-52, fig. 3.) Thus at Dinorben there had been two successive ramparts in the early phase, both of which had been burnt, and the first had probably been largely removed before the second was constructed along its line (FIG. I). That there had, in fact, been a considerable lapse of time between the destruction of the first and the construction of the second is suggested by the radiocarbon dates to be discussed presently. That the first rampart had not been constructed until the settlement had been occupied for some time, is suggested by the shallowness of the palisade trench and by the way in which the pre-rampart occupation layer continues, with diminishing thickness, beyond the palisade trench southwestwards, and beyond the Period II ditch.

The destruction of the Period II rampart had also been thorough. The associated ditch is largely filled with a mixture of lime, charcoal and rubble which spreads down from what little remains of the line of the rampart itself; over this lies a great mass of vari-coloured clays stretching out far beyond the primary ditch upon which stands the inner revetment wall of Dr Gardner's penultimate (Period IV) rampart, here preserved to most of its original height in the body of the Period V rampart (PL. Xxxvilla). It is not clear whether the clay mound on which this penultimate revetment wall stands should be regarded as the remains of a destroyed Period III rampart or whether what Dr Gardner calls the Period IV rampart in his sections should rather be equated with Period III in the south-east entrance: Period IV there, in this case, would be purely local. If, in fact, Periods III and IV in the 1969 section are really one structure any objects contained in the deep deposit of occupation material which accumulated in the hollow between the remains of the Period II rampart and the penultimate revetment wall (PL. Xxxviria) would have provided a terminus ante quem for the date of the latter. Unfortunately, we had no more success than Dr Gardner in finding archaeologically datable objects in these layers or in the prerampart layers: as before, only animal bones and pot-boilers came to light and the only significant objects from the body of the rampart were a few potsherds which had been incorporated in the make-up of the Period I rampart. These are fragments from the fabric of coarse, heavily gritted urns, without rims or shoulders or other features of particular typological significance. These could be interpreted in a North Wales context, either as a local 'Iron Age A' or as a local Late Bronze Age fabric related to the Wessex 'biconical' and bucket urn group recently brought to light at Bromfield (Salop) and Rhuddlan (Flints.).

Convinced that the chronological range of the constructional phases was wide enough to permit a statistical distinction between radiocarbon dates, the writer, with the good offices of Dr Rhys Jones of the Australian National University, Canberra, sent several charcoal samples, taken from burnt layers in the main rampart, mainly from the 1969 section, to the Radiocarbon Dating Laboratory, Institute of Applied Science of Victoria, Melbourne; he also sent, as a control, a charcoal sample from the late Roman layer behind the noth-eastern rampart at Dinorben. He wishes to record his appreciation of the promptness with which Miss A. Bermingham, in charge of the laboratory, arranged for dates to be supplied. The results were startling, but consistent, and may be tabulated as follows (all the dates are based upon the half-life of 5568 years):

V-r23. Charcoal from occupation layer (Period O) underlying rampart of Period I: $945 \pm 95 \mathrm{BC}$.

V-122. Charcoal from collapsed beam to northeast of Period I rampart: $895 \pm 95 \mathrm{BC}$.

$\mathrm{V}$-r25. Charcoal from north-east slope of hollow between Period I-II rampart remains and inner revetment wall of Period IV (probably derived from Period I rampart): $765 \pm 85$ BC.

V-r24. Charcoal from south-east side of hollow between Perion I-II rampart remains and inner revetment wall of Period IV (probably from destruction of Period II). Section SL VI (1969) $535 \pm 85$ BC.

V-r76. Charcoal from charred timber-lacing attached to under surface of lime-heap (= Period II). Section S LVI (1969): $420 \pm$ $70 \mathrm{BC}$. 
A WELSH BRONZE AGE HILLFORT

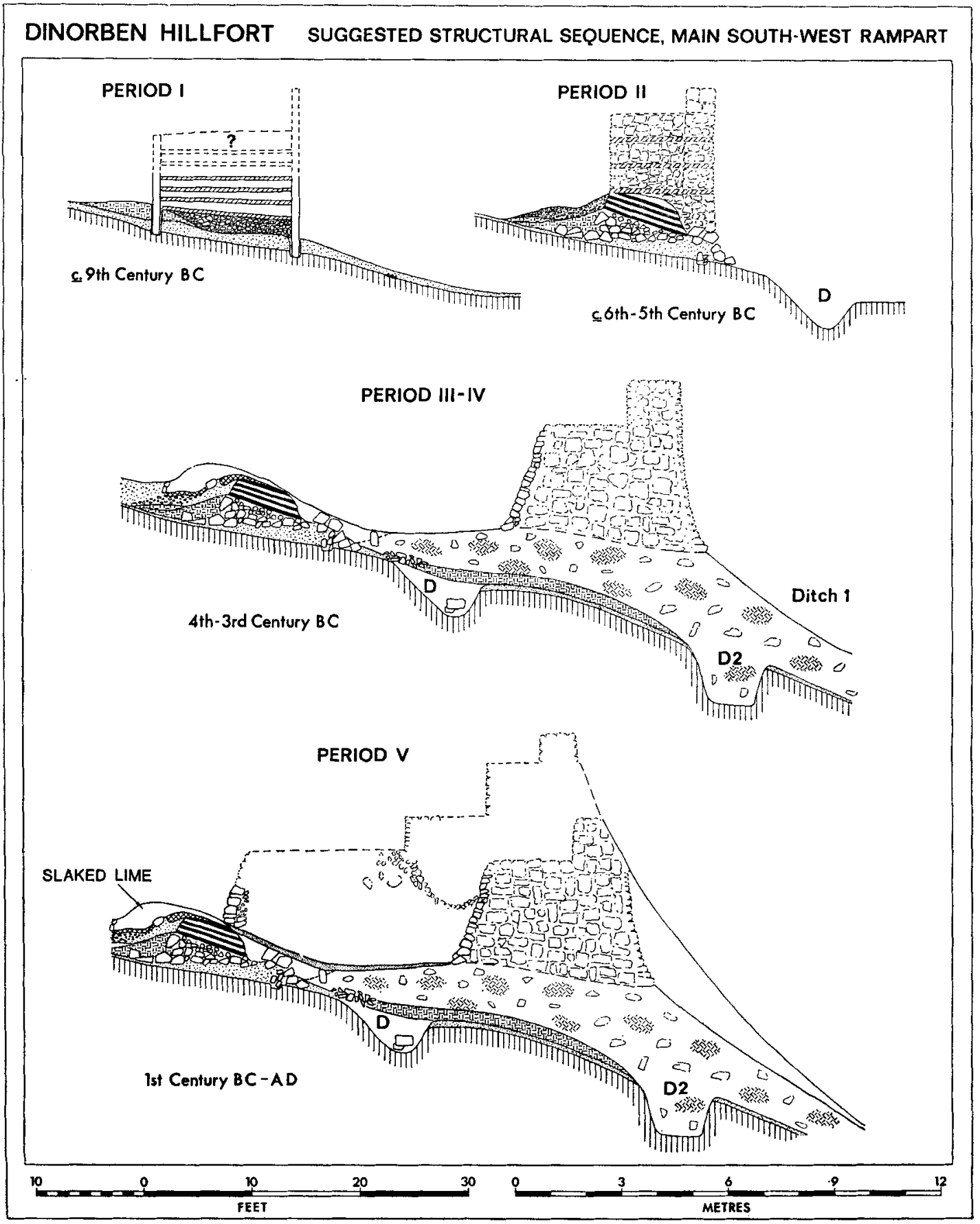

Fig. I

255 


\section{ANTIQUITY}

V-r75. Charcoal from within inner foot of limeheap of Period II, section S LII (1967): $150 \pm 80 \mathrm{BC}$.

V-I77. Charcoal from layer of rubbish derived from late Roman settlement and containing Roman coins (c. AD 270-350): AD $280 \pm 80$.

These dates imply that the first rampart at Dinorben, built of clay and rubble with timber rafts, may have been built during the $9^{\text {th }}$ century BC, allowing for the fact that V-I22 and $\mathrm{V}-125$ are not statistically distinguishable and that 'conventional' radiocarbon dates in the Bronze Age may prove to be a little too low, while the timber-laced rubble rampart of Period II may have been built in the late 6th

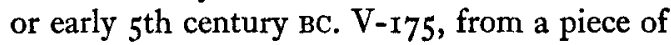
charred timber embedded in the inner foot of the lime-heap derived from Period II in an earlier section, dug in 1967 , clearly cannot be reconciled with V-124, and V-176 which also come from the timber-lacing of Period II, while the last two are not statistically distinguishable from each other. The position of the first sample, however, might be due to disturbance of the lime-heap during Periods III-V. Sample V-I77 is quite consistent with the archaeological dating of the layer from which it came. Unfortunately no charcoal was found which could be directly related to the construction of ramparts III-IV and so to the chronology of the paired guard-chambers in the south-east entrance, but the recent evidence for paired circular guard-chambers having been built at Rainsborough Camp in the Cotswolds (M. Avery, r967, 253-67) early in Iron Age ' $A$ ', and the evidence for paired rectangular guardchambers having first been built at a somewhat later date at Croft Ambrey and Midsummer Hill Camps in Herefordshire (Stanford, 1967, 34-6; 1968; 1969) suggests that Period III-V at Dinorben might easily belong to the $4^{\text {th }}$ or

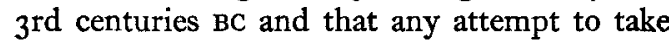
seriously Dr Gardner's record of a Roman pioneer's axe stratified between Periods II and III must be abandoned; perhaps Dr Gardner was misled by his workmen. Full acceptance of a Late Bronze Age date for Periods $\mathrm{O}-\mathrm{II}$ at Dinorben, however, clearly depends upon the establishment of a Late Bronze Age phase in the finds at Dinorben and other hillforts in southern Britain.

Can the old evidence of the Parc-y-meirch hoard now be supplemented by material from within the defences of Dinorben itself? The somewhat ambiguous potsherds already mentioned, from the make-up of the Period I rampart, are at any rate not inconsistent with a Late Bronze Age date. But rather more positive is the evidence of the fragmentary bronze pin found in a pre-rampart hut-floor on the northeast side of Dinorben in $195^{8}$ (FIG. 2.2) (Gardner and Savory, r964, I31 f., fig. 17.r), which was then interpreted as a variant of the familiar Early Iron Age ring-headed pin type, known in Scotland as a 'crook-head' (Stevenson, 1955, 288) and hardly known in other parts of Britain. As Scottish examples are often of iron and the Abernethy culture, with which they seemed particularly to be associated, was then thought to belong to the 3 rd or and century BC it seemed unlikely that the Dinorben example could be much earlier. Now, however, we have radiocarbon indications that some Abernethy forts may have been built as early as the $7^{\text {th }}$ century BC (MacKie, 1969, r6-2r) and it would not now be so daring as it once seemed to compare the British crookhead pins with the continental ones. The latter, in fact, form a welldefined group in the early part of the Late Bronze Age of France (FIG. 2.1), rare east of the Rhine and closely linked with Miss N. K. Sandars's Rilled Ware and the early (Hallstatt 'AI') phase of Urnfield expansion in eastern France, towards the end of the 2nd millennium BC (Sandars, 1957, I $51-4$, 178, fig. 33 and pl. Ix; Ziegert, 1963 , p1. 16 and map 7). The classic sites for this group are the Grotte de Courchapon (Doubs) and the cemetery at Pougues-les-Eaux (Nièvre) (Sandars, 1957, figs. 29-30, 33 and 52), but there is an outlier at Fort Harrouard, in Lower Normandy, with examples of the crookhead pin (Philippe, 1922-4, 39, pl. xiv.12; 1937, fig. 53, 20-21). That this very early Urnfield horizon may be represented even further west in Lower Normandy is suggested by Edeine's recent discovery at the Brèche-auDiable promontory fort, Soumont-St-Quentin, near Falaise, of part of a bronze belt-clasp of a 


\section{A WELSH BRONZE AGE HILLFORT}
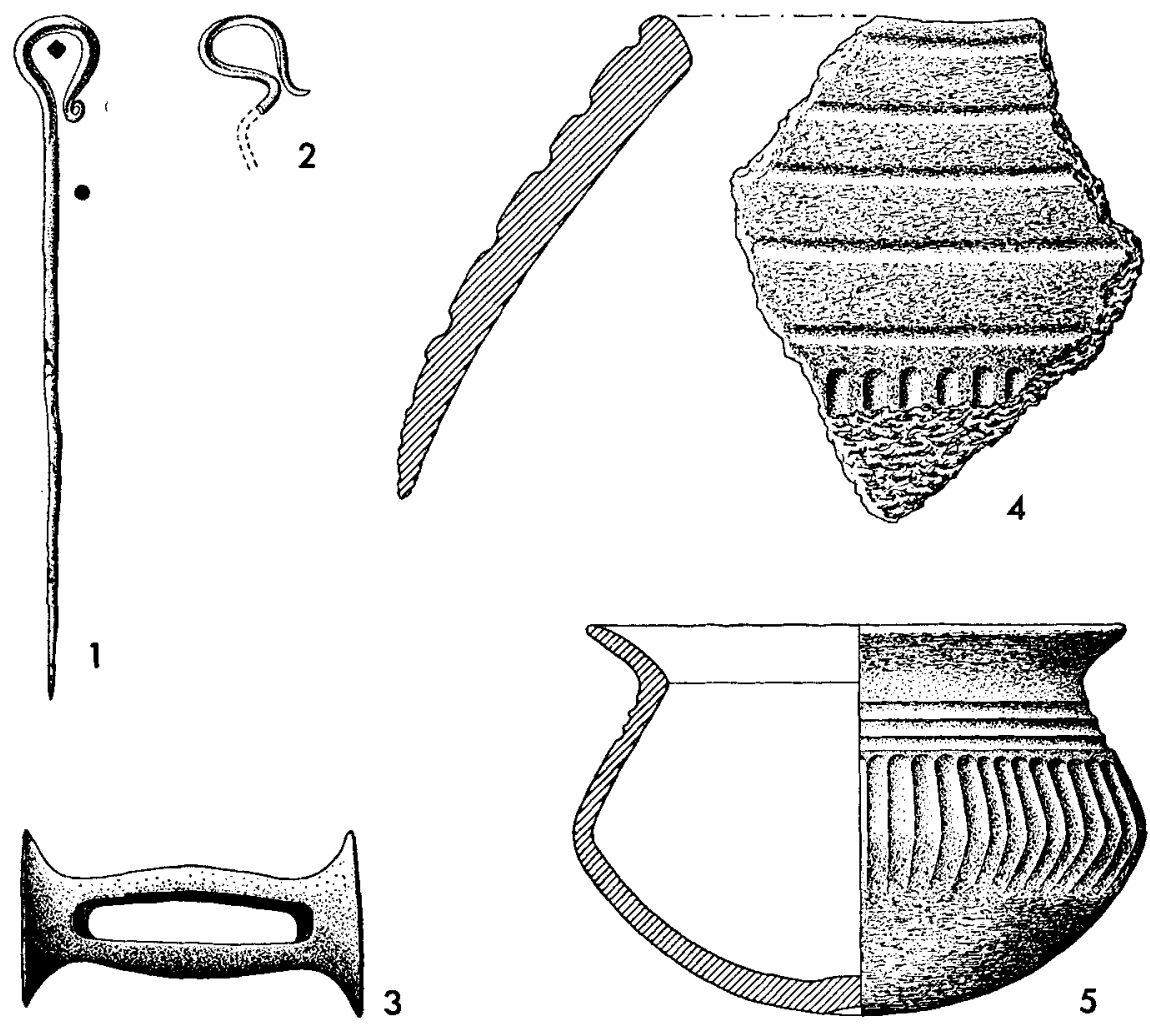

Fig. 2

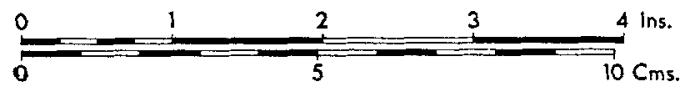

I: Bronze crook-head pin, Les Gours-aux-Lions, Marolles-sur-Marne (Seine-et-Marne); 2 : Head of similarpin from Dinorbenhillfort ; $3:$ Bronze slotted spool from the Parc-y-Meirch hoard (Denbs.); $4:$ Late Bronze Age sherd from Upper Chapel (Brecknock); 5: Rilled Ware bowl from Les Gours-aux-Lions. (I and 5 after C. \& D. Mordant)

type found in Rilled Ware grave groups further east (Edeine, r966, 247-62). There is, of course, no clear evidence as yet that the Rilled Ware group established itself in strength in Lower Normandy, still less that it crossed thence into Wessex and the Welsh Marches in a complete form, and the appearance of a single crook-head pin at Dinorben might be the result of the movements of a hybrid, peripheral group at a considerably later date. But it would be reasonable to consider it as a phenomenon related to that of the Picardy pins which Hawkes studied (Hawkes, 1942, 29-40), and other types of pin connected on the Continent with the later phases of the Urnfield Culture, which occur more plentifully in northern France and lowland Britain. In other words, it might be connected with the movement of a limited number of people from Lower Normandy to the opposite coasts of Britain who, without transforming the local bronze industry or ceramics, introduced a foreign fashion of dress-fastening and certain other continental types which have a limited distribution in Britain, like the single-edged knife in the Ffynnonhau, Brecon, hoard (Burgess, 1968, fig. 2.I). Bronze pins, as is well known, are very rare in Bronze Age hoards but relatively well represented on the settlement 


\section{ANTIQUITY}

sites of the latter part of the period: one might mention the familiar later Urnfield type with head formed of a coiled flat strip, from Ivinghoe Beacon (Cotton and Frere, 1968, fig. I1.13) and Merlin's Cave, Symonds Yat (Phillips, 1931, pl. Ivb.8) and the nail-headed pins from the latter site (ibid,, pl. Ivb. 6-7) and the Heathery Burn Cave (Inventaria Archaeologica GB 55 Io (8), 95-107). Very recently the upper parts of two nail-headed pins, one of a special type, were found, unstratified, at the Breiddin hillfort in Montgomeryshire (Musson, r970, 21 7), where it now seems that an early promontory fort with palisade defences may have existed. Further excavations at this promising site may throw more light on the possibility that the Breiddin, with its earlier finds of Late Bronze Age metalwork (O'Neil, 1937, I14, fig. 5, 4, 7) is a connecting link between the Late Bronze Age settlement at Symond's Yat on the lower Wye valley and Dinorben.

The finds from Merlin's Cave, Symond's Yat, were unfortunately lost when the Bristol University Spelaeological Society's collections were destroyed during the last War, but they included a Class II bronze razor (Phillips, I93 I, pl. Iva) and a bronze slotted reel (ibid, pl. Ivb, 9) which is one of the rare parallels to the reel in the Parc-y-meirch hoard (FIG. 2.3). The latter, because of its associations in the hoard, might reasonably be supposed to have formed part of Late Bronze Age horse-harness, like the jangles (PL. XXXIX) which have been discussed more than once recently. Attention has been drawn to several close parallels to these jangles in hoards of Montelius $\mathrm{V}$ in the Baltic area (Thrane ,1958, 22I-7), but it has been recognized that the Parc-y-meirch examples may have been derived independently from the western Urnfield cultures through central France. In spite of an attempt to use the Irish examples of such jangles to link the Parc-y-meirch specimens with the lately somewhat exaggerated diffusion route from South Scandinavia through northern Britain to Ireland (Rynne, I962, 383-5), it is far more likely that these in fact form part of a complex of horse-harness, represented at Parc-y-meirch and Merlin's Cave, which has roots in France and central Europe rather than
Scandinavia. Apart from the jangles, which are more common in central France on the Hallstatt ' $B$ ' horizon than Thrane's list would suggest* there are the slotted reels, which otherwise occur only in southern England (Inventaria Archaeologica GB I8 3 (3), 29 (Harty); Evans, I88I, 308 (Marden); Burgess, I968, 37 (Isleham); Atkinson, 1965, 132 (Wayland's Smithy) and Hewer, 1925, 216-21, fig. 1.5 (Merlin's Cave)) but relate to a continental Hallstaat ' $B$ ' form. 'There are also the disc mounts with four equidistant slits common to the Parc-y-meirch and Welby (Leics.) hoards (Powell, 1948, 32-4, fig. 3, 9-13) which relate to a continental Hallstatt ' $C$ ' type studied by Kossack (r954, r 58-6r) and Schüle (r969, r9r, map 9).

This harness element, again, is distributed through central Europe to southern France, where it has lately turned up, on headstalls which could be reconstructed, with bridle-bits, in two graves (Nos. 68 and 99, at Grand Bassin, Mailhac (Aude) (O. J. Taffanel, I962, figs, 9-12). Equally interesting is the association of this type with the shipwreck at Rochelongue on the Hérault coast, which yielded a mass of Late Bronze Age objects-swords, socketed axes and spearheads, and razors as well as brooches of Mediterranean types and bracelets of local late Hallstatt types (M. Clavel, 1970, 78-82 and Schüle, I969, r9r). All these associations point to the arrival in Britain of warrior equipment which is connected with the expansion of the Celts in France and may have been in the possession of an immigrant military class in Britain too; there is no evidence for such movements in southern Scandinavia.

Any suggestion that the deposition of horse harness or personal ornaments, like pins, at sites in the Welsh Marches, might reflect the presence of even a limited number of foreigners, more or less recently arrived from the Continent, has to be reconciled with the general assessment of Late Bronze Age culture and especially ceramics in the area, which seems to indicate a continuing evolution in Britain without any

* One should add Chédigny, Indre-et-Loire (Cordier, Millotte and Riquet, I960, III, fig. 7.1 I) and Chaméry, Marne (Doize, 1959, 538, pl. III, 72). 


\section{A WELSH BRONZE AGE HILLFORT}

major interruption from the Continent. The recent finds at Bromfield (Salop) and Rhuddlan (Flints.) seem in fact, to indicate that during the Late Bronze Age the manufacture of coarse bucket- and barrel-shaped urns in the 'Wessex biconical' tradition spread through the Marches and it is probably this tradition that the lost pottery associated with the bronze pins of Urnfield type at Merlin's Cave, Symond's Yat, represented (Phillips, I93I, fig. 3). But it is of interest to draw attention to the decoration of a sherd found some years ago at Upper Chapel in the Epynt region of Brecknock (Savory, 1958, 47, fig. 5). The form and fabric of the vessel represented here (FIG. 2.5) lies within the range of the 'Wessex biconical' tradition-it is of relatively high quality-but the decoration of fine vertical fluting carried, apparently, all round the vessel below a series of fine horizontal furrows has no close parallel in any southern English Late Bronze Age pottery known to me but recalls the standard pattern of the French 'First Urnfield' rilled ware as seen at Pouguesles-Eaux (Sandars, r957, loc. cit.) and the recently published site at Gours-aux-Lions, Marolles-sur-Seine (Seine-et-Marne) (C. and D. Mordant, 1970 , figs. $3,5,8$, I0, $16,20,28,30,32$ and 37 ), which also produced a crook-head pin (ibid, fig. 4.5). Since MacKie has compared an 'everted rim' sherd from Dun Mor Vaul, Tiree (Argyllshire) with the fluted Urnfield fine ware from central France (MacKie, 1969, 22, pl. Va-b) it may not be unreasonable to see in the Upper Chapel potsherd the influence of an Urnfield ceramic tradition, established somewhere in south-west Britain, which remains to be located. As with the Normans, however, the presence of an intrusive military class in Britain in the Late Bronze Age is declared, archaeologically, by military architecture more than anything else, for here there can be no doubt of a cultural innovation.

The evidence, now growing, for the construction of fortifications, from the beginning of the Late Bronze Age in Britain, if not earlier, is the most conclusive indication of a cultural change brought about by an immigrant military class with roots in the interior of France, which was able to divert the energies, previously devoted to the construction of great earthworks for religious ceremonial, to their own security: for it is only in that direction and beyond, in central Europe, that we can find a tradition of military earthwork building in the Bronze Age, the normal expression of which is the promontory fort. Whereas there appears to be no evidence for Bronze Age hillfort architecture in Scandinavia, the western part of the north German plain, or near the Rhine mouth, there is ample evidence for it in central Europe, and promontory forts in particular occur throughout southern Germany, and in a broad zone stretching through north-west Switzerland, Franche-Comté, Burgundy, Lorraine, the lower Loire valley and the western and southern fringes of the Massif Central, as far as the lower Garonne valley, Poitou and Charente. This area corresponds to the heartland of the Urnfield Culture in France, from its earliest phase, and there are a number of promontory forts even on the western fringe which have yielded ample evidence of occupation during the Middle or the Late Bronze Age, if not earlier. It is true that hardly any of these sites have been excavated in a way that would really date their defences satisfactorily, or permit a reliable judgement of their constructional techniques, but the Camp de Ceneret, Quinçay (Vienne) the Camp Allaric, Château-Larcher (Vienne) the Camp de Recoux, Soyaux (Charente), the Camp de Pierre-Dure, Voeuil-et-Giget (Charente) and the Camp de Cordie, Pons (Charente-Maritime) are examples of sites which are locally believed to have been built at some date in the Bronze Age. Further north, the occurrence of two Late Bronze Age hoards within the bounds of a large promontory fort at Amboise on the Loire is of interest (Cordier et al., 1960, I09 f, fig. I; cf. Gallia Préhistoire, I, 1958, 135), but even more significant from our point of view is the group of promontory forts which stretches through Lower Normandy to the Channel coast. Fort Harrouard was occupied in the Neolithic, the Middle and Late Bronze Age, and the Early Iron Age, but its rampart is believed to have had a Late Bronze Age phase of construction (Wheeler and Richardson, 1957, 121); further west Le Chrochemêlier, Igé (Orne) is 


\section{ANTIQUITY}

probably of this date (ibid., I20), while B. Edeine believes that the same is true of the Camp du Mont-Joly, Soumont-St-Quentin (Calvados) and the Camp Romain, Banville (Calvados). The evidence at Mont-Joly is fairly definite, for here Edeine has cut a section through the rampart and claims to have found objects of Middle and Late Bronze Age types in its makeup and on its rear slope. These finds in fact include the belt clasp already mentioned on p. 256 above (Edeine, 1961,1966 and 1969). The importance of these promontory forts, apparently associated with an early expansion of the Urnfield culture towards the English Channel coast, is that they are more likely to have been connected with continental influences in Wessex and the Welsh Marches from the beginning of the Late Bronze Age onwards, than those which occur plentifully in Brittany, mainly along the south coast (Wheeler and Richardson, 1957, 102-I4) and appear to belong mainly to the Early Iron Age.

While there is no reason to doubt that the military engineering of the Urnfield culture was spread to Wessex and the Welsh Marches, along with other archaeological phenomena, down the Seine valley and through Lower Normandy, it is necessary to wait for French excavators in these areas to carry out the fully recorded excavations of hill-fort ramparts which will enable us to compare details of structure. At present we still have to go further afield, to the southern edge of the Urnfield heartland, in north Switzerland, to find a fully recorded section through a promontory fort rampart which will enable us to see the background of our earliest rampart at Dinorben. For at the Horn, Wittnau (Aargau) over thirty years ago the late Dr Bersu explored a vast slopingfronted rampart, originally about $12 \mathrm{~m}$. high and $30 \mathrm{~m}$. wide at the base, which was constructed of clay below and rubble above, held together by a series of horizontal rafts of timbers resting on low walls at vertical intervals of 60-90 cm. (Bersu, 1945, pl. XviII and 1946, fig. 2). This first rampart at the Horn was built during Hallstatt ' $B$ ' towards the end of the $9^{\text {th }}$ century BC, and was destroyed by fire which turned part of the upper layers of rubble into quicklime. It seems that a rampart at the Burgenrain fort, Sissach (Basel) had similar rafts, tied to vertical timbers at the back (Fahrb. Schweiz. Ges. für Urg., 1936, I8 f), and to judge by the old account there may have been something like this at the Camp de Recoux near Angoulême (Dictionnaire Archéologique de la Gaule, II, 651). In general, however, the raft arrangement seems to have been replaced in the final stages of the Urnfield culture and the succeeding Hallstatt Iron Age in west central Europe, by systems of more or less widely spaced transverse and longitudinal timbers, sometimes held in position by dry-stone revetment walls, as in our Abernethy forts and forts in the northern Marches like Ffridd Faldwyn, Montgomery and Maiden Castle, Bickerton (Cheshire), and sometimes tied to rows of vertical timbers flush with inner and outer revetment walls, as in continental forts of the Preist type and many Iron Age ' $A$ ' forts in England. The first of these two varieties is represented, on the Channel coast of France, in the outer line of defence of a promontory fort on the Cap d'Erquy (Côtes-du-Nord) which has lately been dated by radiocarbon to the neighbourhood of the $4^{\text {th }}$ century $\mathrm{BC}$ (Giot and Briard, 1969, 21-36, fig. 2) and the second dry-stone rampart at Dinorben was probably laced in this way (FIG. I). It seems reasonable, therefore, to conclude that the engineer who built the first promontory fort at Dinorben was in touch with a tradition which was specifically linked with the Urnfield culture of west central Europe, and that he may in fact have served a ruling class derived from that direction, most probably via the Paris Basin. Time alone can show how many other forts of this kind were built in the Welsh Marches, but the amount of timber that must have been felled to provide the staging of a rampart like that at Dinorben, about $270 \mathrm{~m}$. long, $3.6 \mathrm{~m}$. wide and at least $3.6 \mathrm{~m}$. high must have been very considerable. We should probably regard its use as a byproduct of a widespread tree clearance in the Vale of Clwyd, resulting from the settlement there of a new agricultural community. 


\section{A WELSH BRONZE AGE HILLFORT}

\section{BIBLIOGRAPHY}

ATkInson, R. J. C. 1965. Wayland's Smithy, Antiquity, $\mathrm{xxxIx}, 126-33$.

AVERY, M. I967. Rainsborough, Northants, England: excavations, 1961-5, Proc. Prehist. Soc., n.s. XxxIII, 207-306.

BERSU, G. r954. Das Wittnauer Horn (Basel). 1946. A hill-fort in Switzerland, Antiquity, xx,4-8.

Burgess, C. B. 1968. The Later Bronze Age in the British Isles and North-western France, Arch. fourn., Cxxv, I-45.

ClAVEL, M. I970. Béziers et son territoire dans l'antiquité (Paris).

CORDIER, G., J.-P. MILLOTTE and R. RIQUET. I960, Trois cachettes de bronze de l'Indre-et-Loire, Gallia Préhistoire, III, 109-28.

COTTON, M. A. 1954. British camps with timber-laced ramparts, Arch. Fourn., cxI, 26-105.

COTTON, M. A., and S. S. FRERE, x968. Ivinghoe Beacon, 1. excavations, I963-5, Records of Bucks., xVIII, $187-260$.

DoIze, R. L. 1959. La cachette de l'Age du Bronze de Chaméry (Marne), Congrès Préhist. Française, XVI, 530-38.

EDEINE, B. I96r. De quelques objets de l'âge du Bronze trouvés dans le départment de Calvados, Bulletin de la Soc. Préhist. Française, LVIII, 676-92.

1966. Le rempart de l'éperon barré de la Brècheau-Diable, Soumont-St-Quentin (Calvados), Gallia Préhistoire, IX, 247-62.

1969. Soumont-St-Quentin, Gallia Préhistoire, XII, 422.

eVANS, J. 1881. Ancient Bronze Implements (London). GARDNER, W. and H. N. SAVORY. I964. Dinorben, $a$ hill-fort occupied in Early Iron Age and Roman times (Cardiff).

GIOT, P.-R. and J. BRIARD. I 969 . Les retranchements du Cap d'Erquy, Annales de Bretagne, Lxxvi, 21-36.

harding, D. 1970. The 'New' Iron Age, Current Archaeology, 20, 235-40.

HAWKES, C. F. C. 1931. Hill-forts, Antiquity, v, 60-97. I942. The Deverel urn and the Picardy pin, Proc. Prehist. Soc., vIII, 26-47.

HEWER, T. F. 1925. Second report on excavations in the Wye valley, Proc. Bristol. Univ. Spelaeol. Soc., II, 3.

Kossack, G. 1954. Pferdegeschirr aus Gräbern der älteren Hallstattzeit Bayerns, Fahrb. Rom. Germ. Komm., Mainz, I, I-x6r.
MackIE, E. I969. Radiocarbon dates and Scottish Iron Age, Antiquity, XLIII, I 5-26.

MORDANT, C. and D. 1970. Le site protohistorique des Gours-aux-Lions (Paris).

musson, c. 1970. The Breiddin 1969, Current Archaeology, 19, 215-8.

O'NEIL, B. H. ST J. I937. Excavations at Breiddin Hill Camp, Montgomeryshire, 1933-5, Arch. Camb., XCrI, 86-I 28.

Philippe, J. 1922-4. Fouilles à Fort Harrouard, Bull. Soc. Norm. Etudes Préhist., $2 \mathrm{I}-39$.

PHILLIPS, C. W. I93I. Final report on the excavation of Merlin's Cave, Symond's Yat. Proc. Bristol Univ. Spelaeol. Soc., IV, I I-33.

Powell, T. G. E. I948. A Late Bronze Age hoard from Welby, Leicestershire, Arch. Fourn., cv, 27-40.

RICE HOLMES, T. 1907. Ancient Britain and the invasions of fulius Caesar (Oxford).

RYNNE, E. 1962. Late Bronze Age rattle-pendants from Ireland, Proc. Prehist. Soc., xxvin, 383-5.

SANDARs, N. K. I 957. Bronze Age Cultures in France (Cambridge).

SAvory, H. N. I958. The Late Bronze Age in Wales, Arch. Camb., cvir, 3-63.

ScHULE, w. I969. Die Meseta-Kulturen der Iberischen Halbinsel (Madrider Forschungen Band 3).

STANFORD, s. C. I967. Croft Ambrey hill-fort, Trans. Woolhope Nat. F.C., xxIx, 31-9.

1968. Midsummer Hill Camp, $3^{\text {rd Int. Report }}$ (Malvern).

1969. Midsummer Hill Camp, 4th Int. Report (Malvern).

STEVENSON, R. B. K. I955. Pins and the chronology of brochs, Proc. Prehist. Soc., XXI, 282-94.

TAFFANEL, o. and J. 1960. Deux tombes de chefs à Mailhac (Aude), Gallia, xx, 1-37.

THRANE, H. I958. The rattle pendants from the Parcy-meirch Hoard, Wales, Proc. Prehist. Soc., XXIV, 22I-7.

WHEELER, R, E. M. 1922. Roman and native in Wales: an Imperial frontier problem, Trans. Hon. Soc. Cymmrodorion I920-21, 40-96.

WHEELER, R. E. M. and K. M. RICHARDSON. I957. Hill-forts of Northern France (London).

zIEGERT, H. 1963. Zur Chronologie und Gruppengliederung der Westlichen Hïgelgraberkultur (Berlin). 


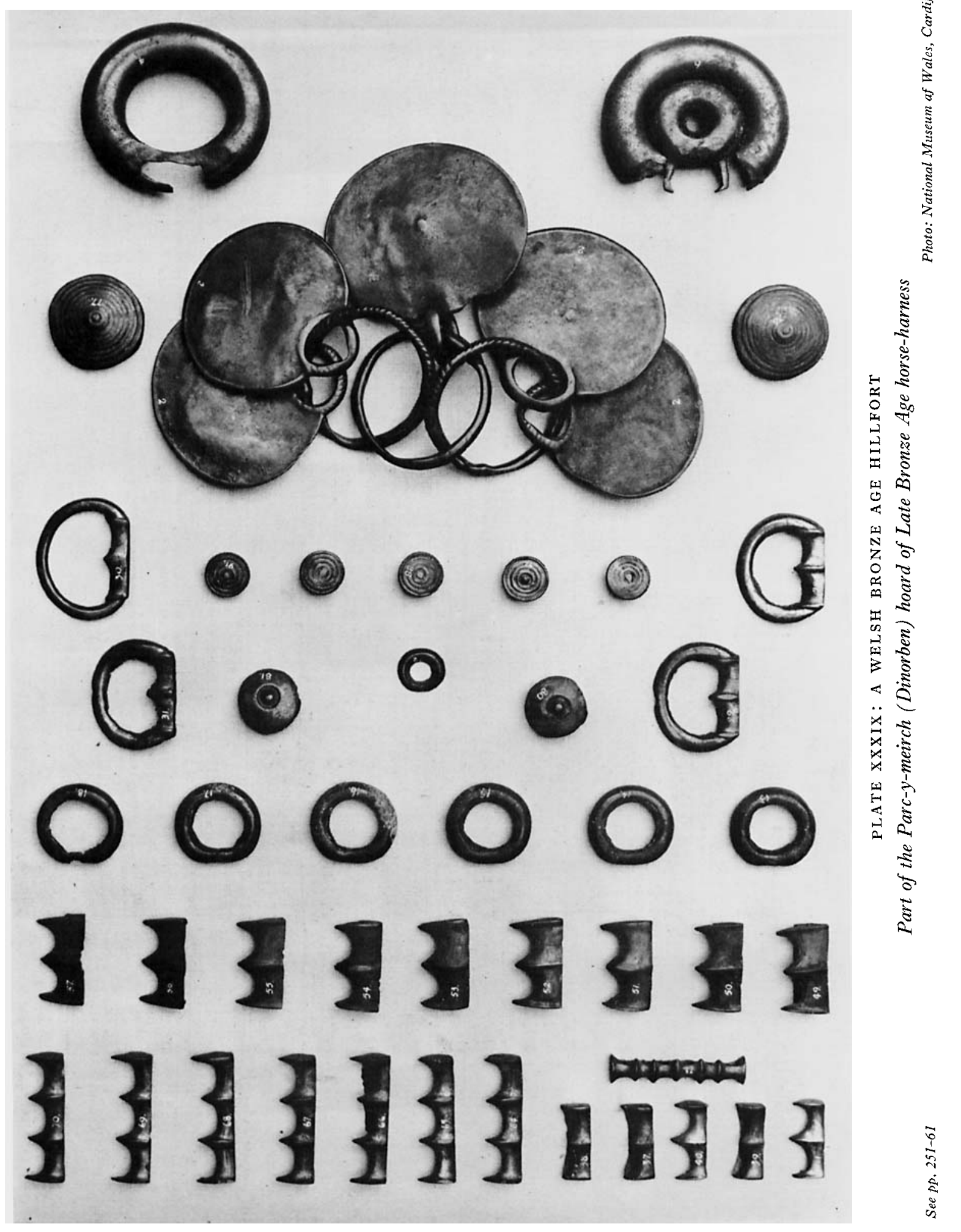

